\title{
Penggunaan Media Kartu Bilangan Untuk Meningkatkan Kemampuan Matematika Siswa Kelas I SD Negeri 078014 Safusi
}

\author{
Sidiwima Gea \\ SDN 078014 Safusi \\ sidiwima66@gmail.com
}

\begin{abstract}
Penelitian ini bertujuan untuk mengetahui kemampuan menjelaskan makna bilangan cacah pada siswa Kelas I SDN 078014 Safusi Kec. Lahewa Timur, Kab. Nias Utara Provinsi Sumatera Utara melalui penggunaan Media kartu Bilangan. Metode penelitian yang digunakan dalam penelitian ini, adalah Penelitian Tindakan Kelas (PTK) model Kemmis dan Taggart dengan langkah-langkah perencanaan, pelaksanaan, observasi dan refleksi. Subjek penelitian merupakan siswa kelas I yang berjumlah 11 orang. Penelitian ini dilakukan pada Semester Ganjil tahun ajaran 2020/2021. Instrumen pengumpulan data yang digunakan dalam penelitian ini adalah lembar tes dan lembar observasi. Data dianalisis dengan menggunakan analisis deskriptif kuantitatif. Berdasarkan hasil analisis data pada proses pembelajaran pada siklus I, bahwa proses pembelajaran Matematika memperlihatkan bahwa kemampuan siswa secara klasikal masih dibawah standar KKM kelas 60 dan nilai rata-rata kelas adalah 63,64\% atau hanya 7 anak yang tuntas. Hasil refleksi siklus II menunjukkan perubahan peningkatan kemampuan siswa yakni sebesar 90,91\% atau sebanyak 10 siswa yang tuntas belajarnya. Dari hasil tersebut dapat disimpulkan bahwa penggunaan media kartu dapat meningkatkan kemampuan menjelaskan makna bilangan cacah pada siswa Kelas I SDN 078014 Safusi Kecamatan Lahewa Timur, Kabupate. Nias Utara Provinsi Sumatera Utara
\end{abstract}

Kata Kunci: Bilangan Cacah, Kartu Bilangan, Kemampuan Matematika

\section{Pendahuluan}

Hasil observasi awal yang dilakukan pada siswa kelas I SDN 078014 Safusi Kec. Lahewa Timur, Kab. Nias Utara Prov. Sumatera Utara diperoleh informasi bahwa hasil belajar Matematika pada materi mengurutkan bilangan cacah yang diperoleh siswa hanya sebesar 4 dari 11 orang siswa atau sebesar $36,36 \%$ siswa yang mendapat nilai di atas KKM kelas 60. Dari pengamatan yang dilakukan pada proses pembelajaran terlihat beberapa orang siswa kurang aktif, cenderung diam saja dan termenung ketika mendengarkan guru menjelaskan materi yang dipelajari.

Pembelajaran matematika di kelas 1 sebagaimana yang terjadi di atas hendaknya segera di atasi, tentu perlu beberapa waktu untuk memperbaiki proses pembelajaran yang terjadi, nilai yang dicapai siswa kurang memuaskan (dibawah rata-rata), pemahaman siswa terhadap mata pelajaran Matematika rendah. Dari 
banyaknya permasalahan di kelas tidak mungkin dapat terselesaikan dalam waktu yang bersamaan. Oleh karena itu, peneliti akan memprioritaskan perbaikan pembelajaran pada peningkatan pemahaman siswa, mengaktifkan siswa menggunakan alat peraga, mendisiplinkan siswa agar memperhatikan pembelajaran sehingga mampu meningkatkan prestasi siswa dalam pembelajaran matematika (Suhartono, 2009).

Pembelajaran Matematika di SD merupakan salah satu kajian yang menarik untuk dikemukakan karena adanya perbedaan karakteristik khususnya antara hakekat anak dan hakekat matematika. Oleh karena itu, diperlukan adanya jembatan yang dapat menetralisir perbedaan tersebut. Anak usia SD sedang mengalami perkembangan pada tingkat berfikirnya. Hal ini dikarenakan tahap berfikir mereka masih belum formal, bahkan tidak jarang para siswa SD di kelas rendah cara berfikirnya masih berada pada tahapan pra-konkrit.

Banyak orang yang tidak menyukai matematika termasuk anak-anak yang masih duduk di bangku sekolah dasar. Mereka menganggap bahwa matematika sulit dipelajari serta gurunya kebanyakan tidak menyenangkan, membosankan dan menakutkan. Anggapan ini menyebabkan mereka semakin takut belajar matematika. Sikap ini tentu saja mengakibatkan prestasi belajar matematika menjadi rendah, akibat lebih lanjut mereka menjadi semakin tidak suka terhadap matematika. Karena takut dan tidak suka belajar matematika, maka prestasi belajar mereka menjadi semakin menurun. Hal ini perlu mendapat perhatian khusus dari para guru khususnya guru sekolah dasar untuk melakukan suatu upaya dalam meningkatkan minat dan prestasi belajar Matematika peserta didiknya.

Salah satu materi yang dipelajari oleh siswa kelas I dalam pembelajaran matematika yaitu materi bilangan. Depdiknas (2003) dalam Prihandoko (2006: 21) menyebutkan "standar kompetensi untuk mata pelajaran matematika pada satuan Sekolah Dasar dan Madrasah Ibtidaiyah meliputi tiga aspek yaitu bilangan, pengukuran dan geometri, serta pengelolaan data". Untuk melakukan pembelajaran matematika yang menarik, pembelajaran yang dapat dilakukan dengan menggunakan media kartu bilangan.Media pembelajaran merupakan hal yang penting ketika menjalankan proses pembelajaran karena media pembelajaran dapat membantu siswa dalam memahami materi pembelajaran (Nasarrudin, 2015:25).

Trisnani (2019) menyatakan bahwa penggunaan media kartu dalam pembelajaran matematika memberikan manfaat untuk memberikan pemahaman siswa mengenai materi pembelajaran matematika yang sedang dipelajari. Media kartu bilangan adalah sebuah media pembelajaran yang digunakan untuk memberikan pemahaman kepada anak tunagrahita, dimana media ini berupa kartu kartu berukuran $10 \times 15 \mathrm{~cm}$ yang memuat simbol bilangan (angka) dan dilengkapi dengan gambar (benda), gambar ini untuk menjelaskan fakta yang berkaitan dengan simbol bilangan pada tiap kartunya, yang berjumlah 10 kartu. Yang dimaksud media kartu gambar ini adalah media yang menghubungkan antara simbol dengan bunyi, antara simbol dengan fakta bilangan.

Media ini penulis rasa cocok untuk anak yang belum memahami konsep bilangan, karena selain menarik, mudah di operasikan, juga cukup efisien. Sebab dapat digunakan secara berulang-ulang tanpa harus mengeluarkan biaya kembali, sehingga cukup ekonomis. Media yang baik adalah media yang sederhana, murah mudah didapat dimana saja, mudah di operasikan serta memiliki daya tarik sehingga menimbulkan motivasi siswa dalam belajar.

Dari hasil uraian latar belakang di atas, tujuan penelitian ini yaitu untuk mengetahui kemampuan menjelaskan makna bilangan cacah pada siswa Kelas I SDN 
078014 Safusi Kecamatan Lahewa Timur, Kabupaten Nias Utara Provinsi Sumatera Utara melalui penggunaan Media kartu Bilangan

\section{Metode}

Metode penelitian ini dilakukan dengan jenis Penelitian Tindakan Kelas (PTK). Penelitian ini terdiri dari 2 siklus dimana masing-masing siklus terdiri dari perencanaan, tindakan, observasi dan refleksi. Berikut penjabaran dari masingmasing tahapan:

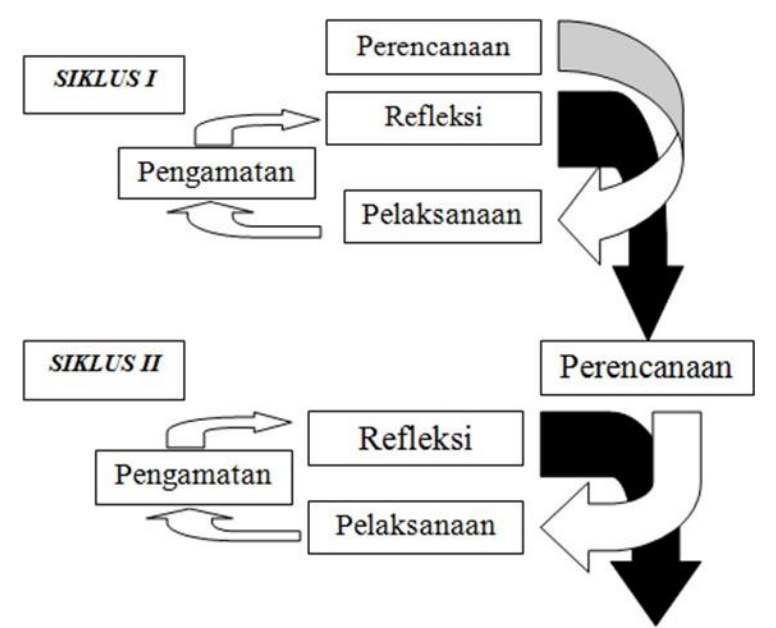

Gambar 1. Proses Penelitian Tindakan Kelas

1) Perencanaan

Pada tahap ini, peneliti menyusun aktivitas-aktivitas pembelajaran matematika dengan menggunakan alat peraga.

2) Pelaksanaan

Pelaksanaan penelitian dilaksanakan sesuai dengan rencana perbaikan pembelajaran yang telah tersusun dalam dua siklus. Dalam tahap ini, peneliti dibantu oleh teman sejawat yang merangkap sebagai observer. Pelaksanaan penelitian secara umum berlangsung mulai dari kegiatan awal, kegiatan inti, kegiatan perbaikan, kegiatan akhir dan tindak lanjut. Sedangkan secara khusus, perbaikan pembelajaran dilakukan melalui aktivitas perbaikan pada kegiatan inti pada siklus I dan siklus II.

\section{3) Pengamatan}

Peneliti dibantu oleh teman sejawat untuk mengidentifikasi kelebihan dan kekurangan dalam perbaikan pembelajaran yang dilaksanakan. Oleh pengamat, kekurangan dan kelebihan itu dicatat dalam lembar observasi. Pada akhir pelaksanaan perbaikan pembelajaran, peneliti mengadakan tes perbaikan atau evaluasi.

4) Refleksi

Setelah melaksanakan tindakan dan pengamatan, peneliti mengadakan diskusi dengan teman sejawat dan supervisor untuk mengetahui kemampuan siswa dalam menyelesaikan soal-soal menjelaskan makna bilangan cacah menggunakan alat peraga kartu bilangan. 


\section{Partisipan}

Subjek penelitian ini adalah siswa kelas 1 Kelas I SDN 078014 Safusi Kecamatan Lahewa Timur, Kabupaten Nias Utara Provinsi Sumatera Utara yang berjumlah 10 orang siswa. sekolah ini berada di wilayah terluar Pulau Sumatera, yaitu Pulau Nias yang dapat ditempuh selama 10-12 jam dari Kota Medan.

\section{Instrumen}

Instrumen pengumpulan data yang digunakan dalam penelitian ini, yaitu lembar tes tertulis dalam bentuk soal tes uaraian. Soal tes ini digunakan untuk mengukur kemampuan menjelaskan makna bilangan cacah. Serta lembar catatan lapangan untuk mengukur aktivitas, keaktifan, dan perubahan tingkah laku peserta selama pelatihan.

\section{Teknik Pengumpulan Data}

Teknik yang digunakan untuk mengumpulkan data adalah teknik tes dan non tes. Teknik tes yang digunakan dalam penelitian ini adalah tes tertulis bentuk uraian. Tes ini digunakan untuk memperoleh data mengenai pemahaman Matematika dengan menggunakan metode De-si. Teknik non-tes berupa observasi dengan lembar observasi dan catatan harian yang digunakan untuk menilai aktivitas, keaktifan, dan perubahan tingkah laku peserta selama pelatihan.

\section{Teknik Analisis Data}

Analisis data dalam penelitian ini disajikan dalam bentuk analisis kualitatif dengan metode pemaparan secara deskriptif komparatif, yakni mendeksripsikan semua temuan dalam penelitian disertai dengan data-data kuantitatif yang dianalisis secara sederhana (persentase) dan deskriptif interpretatif.

1. Data yang sudah terkumpul akan dianalisis secara kuantitatif dan kualitatif, yaitu menggunakan:

Data kuantitatif berupa hasil belajar kognitif, dianalisis dengan menggunakan teknik analisis deskriptif dengan menentukan rerata atau mean. Adapun penyajian data kuantitatif dipaparkan dalam bentuk presentase dengan rumus:

$$
\text { Skor Perolehan: } \frac{\text { Skor Perolehan }}{\text { Skor Maksimal }} \times 100 \%
$$

Hasil penghitungan dikonsultasikan dengan kriteria ketuntasan belajar siswa yang dikelompokkan kedalam dua kategori tuntas dan tidak tuntas dengan criteria sebagai berikut:

Tabel 1. Kriteria Ketuntasan Belajar Siswa

\begin{tabular}{cc}
\hline Kriteria Ketuntasan & Kualifikasi \\
\hline$\geq 60$ & Tuntas \\
\hline$<60$ & Tidak Tuntas \\
\hline
\end{tabular}

2. Data kualitatif berupa data hasil observasi aktifitas siswa, aktifitas guru dalam pembelajaran mengurutkan bilangan serta hasil catatan lapangan dan wawancara dianalisis dengan deskriptif kualitatif. 


\section{Hasil}

Penelitian dilaksanakan dalam 2 siklus. Penyampaian hasil penelitian pada masing-masing siklus mencakup penilaian penampilan perbaikan pembelajaran dan hasil belajar. Sebelum dberikan tindakan diperoleh data analisis dari hasil ulangan siswa kelas I sebagai berikut:

Tabel 2. Perolehan Nilai Pra siklus

\begin{tabular}{cccc}
\hline No. & Nilai Perolehan & Jumlah Siswa & Presentase \\
\hline 1 & $<60$ & 9 & $90 \%$ \\
\hline 2 & $>61$ & 1 & $10 \%$ \\
\hline & Jumlah & 10 & $100 \%$ \\
\hline
\end{tabular}

Dari tabel 2 di atas dapat diketahui dalam kegiatan pra siklus, nilai yang diperoleh siswa masih di bawah 60 dengan jumlah siswa sebanyak 9 orang dengan presentase sebesar 90\%. Untuk itu perlu dilakukan kegiatan Penelitian tindakan kelas (PTK) pada siklus I.

Pada pembelajaran siklus I, guru melaksanakan pembelajaran dengan menggunakan media kartu bilangan. Kartu bilangan yang digunakan dibuat sendiri oleh guru sesuai dengan perencanaan yang dilakukan. Dalam memberikan materi kepada siswa, guru menggunakan ceramah yang dibantu dengan media power point sedangkan kartu bilangan dipegang sendiri oleh siswa. agar siswa dapat terlibat langsung dalam kegiatan pembelajaran. Selain itu, guru juga memberikan banyak latihan kepada siswa, baik latihan tertulis maupun latihan dengan menggunakan alat peraga yang dapat memudahkan siswa. Berikut adalah hasil analisis ulangan siswa setelah diberikan tindakan pada siklus I.

Tabel 3. Perolehan Nilai Siklus I

\begin{tabular}{cccc}
\hline No. & Nilai Perolehan & Jumlah Siswa & Presentase \\
\hline 1 & $<60$ & 5 & $50 \%$ \\
\hline 2 & $>61$ & 5 & $50 \%$ \\
\hline & Jumlah & 10 & $100 \%$ \\
\hline
\end{tabular}

Dari tabel di atas, dapat diketahui bahwa dalam proses pembelajaran siklus I jumlah siswa yang lulus dengan nilai di atas KKM sebesar presentase 70\%. Dari hasil refleksi yang dilakukan, diperoleh informasi bahwa, kelemahan pembelajaran pada siklus I yang ditemukan antara lain tugas yang diberikan kepada siswa masih kurang dan guru juga masih kurang dalam memberikan bimbingan dan memotivasi siswa untuk aktif dalam kegiatan belajar. Sehingga, perlu dilanjutkan ke siklus II.

Pada pembelajaran siklus II kegiatan pembelajaran lebih difokuskan pada upaya meningkatkan kemampuan menjelaskan bilangan cacah. Kegiatan pembelajaran yang digunakan tetap sama dan guru lebih sistematis dalam merencanakan diskusi kelompok agar kegiatan diskusi dapat berjalan lebih baik. Setelah itu siswa diberikan kesempatan untuk berdiskusi dan menanyakan kesulitan yang dialaminya selama proses pembelajaran, sehingga guru dapat langsung melakukan pendekatan kepada masing-masing siswa. Selain itu, guru juga 
melakukan perbaikan alat peraga agar dalam menjelaskan materi siswa lebih mudah dipahami. Dengan penggunaan alat peraga dan pemberian latihan soal yang cukup bagi siswa terbukti siswa lebih aktif dalam kegiatan pembelajaran dan hasil yang diperoleh siswa cukup memuaskan. Berikut adalah hasil analisis ulangan siswa setelah diberikan tindakan pada siklus II

Tabel 4. Perolehan Nilai Siklus II

\begin{tabular}{cccc}
\hline No. & Nilai Perolehan & Jumlah Siswa & Presentase \\
\hline 1 & $<60$ & 1 & $10 \%$ \\
\hline 2 & $>61$ & 9 & $90 \%$ \\
\hline & Jumlah & 10 & $100 \%$ \\
\hline
\end{tabular}

Dari tabel 4. Diatas dapat diketahui bahwa siswa yang mendapat nilai $>61$ berjumlah 9 orang dengan presentase sebesar $90 \%$. Sehingga dapat disimpulkan bahwa pembelajaran dengan menggunakan media kartu bilangan dapat meningkatkan kemampuan menjelaskan bilangan cacah pada siswa kelas I di Kelas I SDN 078014 Safusi Kecamatan Lahewa Timur, Kabupaten Nias Utara Provinsi Sumatera Utara.

\section{Pembahasan}

Pelaksanaan penelitian penggunaan media kartu bilangan untuk meningkatkan kemampuan menjelaskan bilangan cacah pada siswa kelas I di Kelas I SDN 078014 Safusi Kecamatan Lahewa Timur, Kabupaten Nias Utara Provinsi Sumatera Utara. Kegiatan penelitian ini dimulai dari tahap perencanaan dengan melakukan kegiatan (1) observasi kemampuan awal peserta didik; (2) menganalisis kompetensi yang akan dikuasai oleh peserta didik; (3) membuat media kartu bilangan; dan (4) mengembangkan instrumen penelitian sesuai dengan indikator yang telah ditetapkan. Langkah pembelajaran ini sesuai dengan kegiatan yang dilakukan oleh penelitian (Prasetyo, Dadi and Anggraini, 2020).

Dari hasil pelaksanaan pembelajaran yang dilaksanakan selama 2 siklus kegiatan, diperoleh hasil belajar siswa pada kemampuan menjelaskan bilangan cacah sebagai berikut, yaitu:

\begin{tabular}{ccccc}
\hline No. & Pelaksanaan & Jumlah siswa tuntas & Prosentase & Keterangan \\
\hline 1 & Prasiklus & 1 & $10 \%$ & Minimal \\
\hline 2 & Siklus I & 5 & $50 \%$ & Meningkat \\
\hline 3 & Siklus II & 9 & $90 \%$ & Maksimal \\
\hline
\end{tabular}

Untuk memudahkan perbandingan hasil kemampuan matematika siswa, berikut disajikan gambar grafik di bawah ini. 


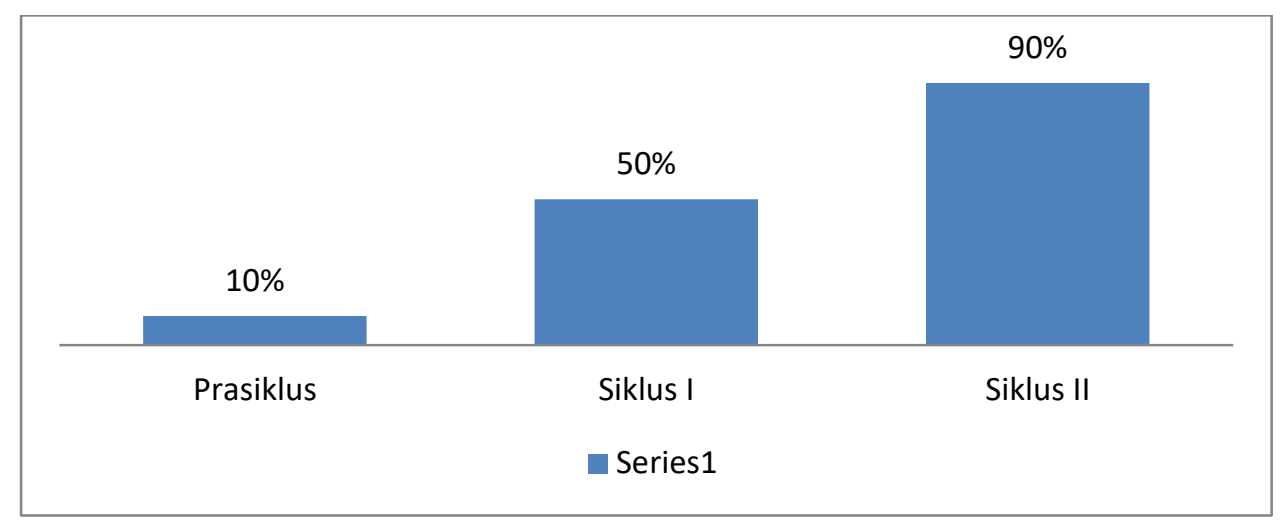

Gambar 2. Hasil Perolehan Nilai Setiap Siklus

Dari hasil penelitian yang dilakukan, pada tahap pra siklus suasana proses kegiatan belajar mengajar terlihat masih kurang aktif dan interaksi guru dengan siswa cenderung masih satu arah. Perolehan nilai dari hasil tes formatif sangat rendah. Dari 10 siswa, tingkat ketuntasan baru mencapai 10\% yang memperoleh nilai $>60$. Setelah diadakan tindakan pembelajaran pada siklus I ternyata perolehan nilai tes formatif mengalami kenaikan. Rata-rata kelas mencapai 50\%. Nilai tertinggi yang diperoleh anak mencapai 100 sedangkan nilai terendah mencapai 40. Dengan demikian masih perlu diadakan perbaikan pembelajaran pada siklus II agar hasil belajar siswa mencapai nilai maksimal.

Kekurangan yang terjadi pada siklus I diantaranya karena guru kurang dalam memanfaatkan alat peraga dan kurang memberikan latihan. Oleh karena itu, dalam rangka meningkatkan pemahaman siswa terhadap materi mengurutkan bilangan, guru memberikan konsep tentang mengurutkan bilangan secara mendalam kepada siswa. Pada siklus II, nilai tertinggi mencapai 100 sedangkan nilai terendah mencapai 50. Hasil tes formatif yang diperoleh siswa meningkat dengan rata-rata $90 \%$ tuntas. Perolehan nilai sebagian besar siswa sudah mencapau 60 ke atas. Maka perbaikan pembelajaran dapat dinyatakan berhasil melalui siklus II. Hasil penelitian ini sesuai dengan penelitian Kusumawinata (2009) yang menyatakan bahwa media permainan kartu angka dalam upaya meningkatkan prestasi belajar siswa pada pembelajaran matematika. Demikian juga Herawati (2012) menyatakan hasil belajar matematika tentang materi penjumlahan dan pengurangan bilangan cacah dapat ditingkan dengan menggunakan media kartu bilangan pada siswa kelas I B Sekolah Dasar Negeri Caturtunggal 4, Depok, Sleman, Yogyakarta.

\section{Kesimpulan}

Dari hasil penelitian yang telah dilaksanakan dapat ditarik kesimpulan bahwa Penggunaan alat peraga dalam kegiatan pembelajaran Matematika sangat berpengaruh dalam meningkatkan hasil belajar siswa. dengan menggunakan kartu bilangan dapat mempermudah siswa dalam memahami konsep awal serta menambah keterampilan dan kemampuan siswa dalam belajar Matematika. Media kartu bilangan juga dapat menjadikan siswa lebih aktif dalam kegiatan pembelajaran Matematika, serta meningkatkan kemampuan siswa dalam mengurutkan bilangan.

\section{Saran}

Berdasarkan hasil penelitian dan simpulan di atas, agar pembelajaran menggunakan kartu bilangan dapat berjalan optimal hendaknya dalam setiap 
kegiatan pembelajaran para guru diharapkan untuk menggunakan media atau alat peraga untuk mempermudah siswa dalam memahami materi pembelajaran. Sebaiknya dalam setiap kegiatan pembelajaran sebaiknya guru memilih metode pembelajaran yang tepat sehingga dapat membangkitkan kreatifitas siswa dalam belajar. Saran dapat berupa tindak lanjut yang dapat dilakukan pihak lain, baik berupa penerapannya oleh praktisi di lapangan, ataupun kajian lebih lanjut oleh peneliti lain.

\section{Referensi}

Indriani. 2013. Penggunaan Media Kartu Bilangan untuk Meningkatkan Kemampuan Konsep Bilangan 1-5 pada Anak Tunagrahita Ringan. Jassi_Anakku. Volume 12 Nomor 2, Tahun 2013. https://ejournal.upi.edu/index.php/jassi/article/view/4060

Herawati, Erna. (2012) Penggunaan Kartu Bilangan Sebagai Media Pembelajaran Untuk Meningkatkan Hasil Belajar Matematika Siswa Kelas I SD Negeri Caturtunggal 4 Depok. S1 thesis, Universitas Negeri Yogyakarta.

Kusumawinata, I Made. (2009) Pemanfaatan Media Permainan Kartu Angka dalam Upaya Meningkatkan Prestasi Belajar Siswa pada Pembelajaran Matematika dalam Operasi Hitung Bilangan Cacah Di SD (Studi di Kelas II SD Negeri Girimargo 1 Kecamatan Miri Kabupaten Sragen). Under Graduates thesis, Universitas Negeri Semarang.

Nasaruddin. (2015). Media dan Alat Peraga Dalam Pembelajaran Matematika. Jurnal Al-Khwarizmi, Volume III, Edisi 2, Oktober 2015, Hal. 21 - 30

Prihandoko, Antonius Cahya. 2006. Pemahaman Penyajian Konsep Matematika Secara Benar dan Menarik. Direktorat Jendral Pendidikan Tinggi Departemen Pendidikan Nasional.

Prasetyo, J., Dadi, S. and Anggraini, D. (2020) 'Pengembangan Rencana Pelaksanaan Pembelajaran Menggunakan Model Project Based Learning (PjBL) Pada Pembelajaran Tematik di Kelas IV SD Negeri Kota Bengkulu', Juridikdas Jurnal Riset Pendidikan Dasar, 3(2), pp. 125-135. Available at:

https://ejournal.unib.ac.id/index.php/juridikdasunib/article/view/14484 (Accessed: 17 March 2021).

Trisnani, Novy. 2019. PENINGKATAN HASIL BELAJAR MATEMATIKA MATERI PECAHAN SEDERHANA MELALUI MEDIA KARTU PECAHAN DI SDN KASATRIYAN. Prosiding Seminar Nasional PGSD UST 